УдК 616.62-003.7- 616-089

DOI 10.11603/2414-4533.2016.4.7192

( С А. Д. БЕДЕНЮК, В. В. ТВЕРДОХЛІБ, А. І. МИСАК, С. О. НЕСТЕРУК

ДВНз “Тернопільський державний медичний університет імені І. Я. Горбачевського”

\title{
Досвід застосування сучасних методів лікування сечокам'яної хвороби
}

\author{
A. D. BEDENYUK, V. V. TVERDOKHLIB, A. I. MYSAK, S. O. NESTERUK \\ I. Horbachevsky Ternopil State Medical University
}

\section{OUR EXPERIENCE OF MODERN TREATMENT METHODS OF UROLITHIASIS}

\begin{abstract}
На основі операційного лікування 56 хворих на сечокам’яну хворобу доведено ефективність використання сучасних малоінвазивних методів, застосування яких дозволяє скоротити терміни стаціонарного лікування та період непрацездатності.

Based on the surgical treatment of 56 patients with urolithiasis there was proven efficiency of modern minimally invasive techniques, the application which allows you shortening the period of hospital treatment and disability.
\end{abstract}

Постановка проблеми і аналіз останніх досліджень та публікацій. Сечокам'яна хвороба - одне з найбільш поширених захворювань, від якого страждають 1-3 \% населення земної кулі. В Україні хворіють 11-16 \% дорослих. Близько 70 \% становлять пацієнти працездатного віку [1, 8]. Сечокам'яна хвороба зустрічається в чоловіків у 2 рази частіше, ніж у жінок. У деяких районах (“ендемічні зони”) внаслідок місцевих особливостей (жорсткість води, особливості харчування, клімат та ін.) сечокам'яна хвороба трапляється особливо часто. Камені в нирках і сечових шляхах виявляють приблизно у 30 \% урологічних хворих хірургічного профілю. На вибір методу лікування впливають не тільки розміри, локалізація каменя, але й активність пієлонефриту, ступінь порушення уродинаміки, функція нирки та багато інших чинників, які необхідно враховувати $[2,5]$. Завдяки технічному прогресу в медицині за останні 10 років стало можливим застосовувати контактні та дистанційні методи руйнування каменів різних локалізацій, значно знизилась кількість відкритих операційних втручань і гнійно-деструктивних ускладнень з приводу конкрементів нирок та сечоводів $[4,6]$.

Мета роботи: поліпшити результати лікування у хворих на сечокам'яну хворобу.

Матеріали і методи. В урологічному відділі КЗ ТОР “Тернопільська університетська лікарня”, що є клінічною базою кафедри хірургії № 1 з урологією імені Л. Я. Ковальчука ТДМУ іме- ні I. Я. Горбачевського, за період 2015-2016 рр. проведено порівняльний аналіз результатів дистанційної ударно-хвильової літотрипсії (ДУХЛТ), контактної літотрипсії (КЛТ) з уретеролітоекстракцією і черезшкірною (перкутанною) нефролітотрипсією (ПНЛ) у 56 хворих із сечокам'яною хворобою.

Результати досліджень та їх обговорення. При проведенні першого сеансу ДУХЛТ повної фрагментації конкрементів було досягнуто в 79,3 \% хворих. У 25 \% із зазначених пацієнтів ми спостерігали напади ниркових колік, викликаних відходженням фрагментів каменя, з них двом хворим було встановлено нирковий стент у зв'язку 3 частим повторенням ниркової коліки. Повне самостійне відходження фрагментів у стаціонарі спостережено у 18 \% хворих, решту пацієнтів виписано на амбулаторне лікування. Середній післяопераційний ліжко-день становив 9,2. Ефективність ДУХЛТ залежала від тривалості перебування каменя на одному місці та від його розміру. Так, при знаходженні каменя на одному місці більше 4 тижнів лише 2 рази вдалося фрагментувати конкремент і домогтися відходження фрагментів за один сеанс. У 2 хворих з конкрементами сечовода більше 1,5 см і тривалістю перебування каменя в одному місці сечовода понад 4 тижні після декількох сеансів ДУХЛТ потрібно було виконати контактну літотрипсію. Спостереженнями підтвердилось, що чим більший розмір конкрементів, тим більша ймовірність повторних втручань. Піс- 
ля проведеної ДУХЛТ активну фазу пієлонефриту зафіксовано у 21,7 \% пацієнтів. Всім цим хворим проведено стентування нирки аж до повного відходження фрагментів каменя.

Контактною літотрипсією вдалося роздробити та видалити конкременти нижньої третини сечоводів у 91,4 \% пацієнтів. У трьох пацієнтів ми не змогли виконати уретероскопію через звуження та девіації інтрамурального відділу сечовода, де було проведено трансуретральну резекцією вічка сечовода з подальшою катетеризацією сечовода i КЛТ. Крім того, в одному випадку сталася дислокація конкремента в ниркову миску. Після сеансу контактної літотрипсії у 22,8 \% хворих мало місце загострення хронічного пієлонефриту, у 8,5 \% - короткотривала макрогематурія, у 5,7 \% пацієнтів короткочасні дизуричні явища, що потребувало призначення антибактеріальної терапії. Післяопераційний період складав 4-6 діб.

Перкутанну нефролітотомію виконано 14 хворим із коралоподібним нефролітіазом. Без особливостей проведення ПНЛ виконано у 60 \% випадків. Насамперед, виявилися труднощі з доступом при ПНЛ. Одиничний доступ був виконаний у 65 \% випадків; операцію виконували з двома доступами у 25 \% випадків; з трьома доступами - у $10 \%$ випадків. Основною причиною ускладнень була ниркова аномалія. Серед вагомих ускладнень при ПНЛ в одному випадку відмічали масивну кровотечу, яку було зупинено шляхом перетискання нефростомічного дренажу. На основі нашого досвіду застосування ПНЛ в лікуванні пацієнтів із великими і коралоподібними конкрементами нирки вдалося довести високу ефективність та безпеку даної процедури при найбільш тяжкій формі нефролітіазу. Крім того, було про-

\section{СПИСОК ЛІТЕРАТУРИ}

1. Боржієвський Ц. К. Вибір оптимального лікування хворих уретеролітіазом / Ц. К. Боржієвський, А. Ц. Боржієвський // Праці VIII пленуму Асоціації урологів України. - К., 1998. - С. 51-52.

2. Боржієвський А. Ц. Електрогідравлічна літотрипсія (ЕГЛ) у лікуванні хворих з каменями сечоводу / А. Ц. Боржієвський // Праці VIII пленуму Асоціації урологів України. K., 1998. - С. 78-79.

3. Пневматична уретеролітотрипсія в лікуванні хворих з каменями сечоводів / М. Белда, Р. Гербець, Є. Лоренц [та ін.] // Матеріали наукових праць Першого українсько-польського симпозіуму урологів. - Львів, 2000. - С. 190-193.

4. Kok D. J. Metaphylaxis, diet and lifestyle in stone disease / D. J. Kok // Arab Journal of Urology. - 2012. - Vol. 10, № 3. P. 240-249. демонстровано сприятливий вплив ПНЛ на збереження і поліпшення функціонального стану нирки в довгостроковій перспективі. Отримані відомості про роль різних прогностичних факторів у поліпшенні показників ефективності та безпеки ПНЛ підвищують можливість впливу на ці ключові параметри лікування пацієнтів даної категорії i, отже, перспективу забезпечення збереженої функції нирки у віддаленому післяопераційному періоді. Післяопераційний період складав 6-7 діб.

Після видалення каменя 3 нирки, ліквідації явищ пієлонефриту доцільно хворого (після виписування зі стаціонару) направити на санаторно-курортну реабілітацію. Це покращує показники аналізів крові та сечі, знижує рецидивне каменеутворення і скорочує період непрацездатності [7, 3].

Висновки. 1. Великий розмір конкремента і тривале його перебування на одному місці в сечоводі збільшують ризики ускладнень і частоту повторних втручань після ДУХЛТ, тому при великих конкрементах ниркової миски (більше 25 мм) краще виконувати перкутанну нефролітотрипсію, а не ДУХЛТ. 2. Контактна ретроградна (трансуретральна) літотрипсія є високоефективним методом малоінвазивного лікування конкрементів нижньої третини сечовода, проте не може бути рекомендована як метод лікування при великих конкрементах верхніх відділів сечовода і нирки.

3. Перкутанна нефролітотрипсія $\epsilon$ високоефективним та малоінвазивним методом лікування хворих із коралоподібним нефролітіазом.

Перспективи подальших досліджень. Додаткове накопичення та аналіз клінічного матеріалу, впровадження сучасних методик ендоурології.

5. Kupajski M. Modern management of stone disease in patients with a solitary kidney / M. Kupajski, M. Tkocz, D. Ziaja // Wideochir Inne Tech Malo Inwazyjne. - 2012. - Vol. 7, No. 1. - P. 1-7.

6. Is there still a role for open surgery in the management of renal stones? / G. Alivizatos, A. Skolarikos // Curr. Opin. Urol. 2006. - Vol. 16, No. 2. - P. 106-111.

7. Outcome of shock wave lithotripsy as monotherapy for large solitary renal stones ( $>2 \mathrm{~cm}$ in size) without stenting / S. Rajaian, S. Kumar, G. Gopalakrishnan [et al.] // Indian J. Urol. - 2010. Vol. 26, No. 3. - P. 359-363.

8. Mahboub M. R. Percutaneous nephrolithotomy in patients with solitary kidney / M. R. Mahboub, M. H. Shakibi // Urol. J. 2008. - Vol. 5, No. 1. - P. 24-27.

Отримано 04.05.16 